\title{
後頭蓋窩AVM に対する摘出術
}

一一特に，治療成績不良例の検討

\author{
宮坂 佳男, 倉田彰, 田中 柳水, 山田勝 \\ 永井 成樹, 常盤 嘉一, 大桃 丈知, 三枝 宏伊 \\ 矢田 賢三, 北原 孝雄, ${ }^{*}$ 大和田 隆*
}

\section{Surgical Treatment for Arteriovenous Malformations in the Posterior Fossa: With Special Reference to Cases with an Unsatisfactory Outcome}

Yoshio Miyasaka, M.D., Akira Kurata, M.D., Ryusui Tanaka, M.D.,

Masaru Yamada, M.D., Shigeki Nagai, M.D., Kaichi Tokiwa, M.D.,

Taketomo Ohmomo, M.D., Hirotada Saegusa, M.D., Kenzoh Yada, M.D.,

Takao Kitahara, M.D., ${ }^{*}$ and Takashi Ohwada, M.D. ${ }^{*}$

Departments of Neurosurgery and ${ }^{*}$ Critical Care Medicine, Kitasato University

School of Medicine, Sagamihara, Japan

Summary : The authors have already reported surgical problems of poor-risk patients with hemorrhagic infratentorial arteriovenous malformations (AVMs). In the presents study, fifteen good-risk patients of infratentorial AVMs, whose levels of consciousness was 0 to 30 according to the Japan Coma Scale, were reviewed and the problems of the surgical treatment are reported. Of this series, 12 patients had a good result, and 3 patients a poor result. Giant AVM and AVM extending from the cerebellum to the brainstem showed an unsatisfactory surgical result. Two out of 3 poor results were due to massive postoperative hemorrhage, related to a residual nidus in the brainstem in one patient, and probably related to a sudden rise in intravascular pressure after removal of giant AVM in one. The present study suggests that presurgical multiple-staged embolization of nidus and a strict control of postoperative systemic blood pressure are important in order to reduce surgical risks of giant AVMs. Furthermore, stereotactic radiosurgery must be considered in combination with surgical treatment for an AVM involving the brainstem.

\section{はじめに}

脳動静脈奇形 $(A V M)$ に対する外科的治療は出血後に重 篤な神経脱落症状を示す重症例に対する救急治療と症状が 軽い軽症例に対する治療に大別される. 特に, 後頭蓋窩
AVM では，重症例の比率が高く，これらの症例に対する 治療方針および成績については既に報告した6). 今回は後 頭蓋窩 AVM 軽症例で術後に悪化した症例を提示して, その原因と今後の対策について報告する。

北里大学 脳神経外科, *同 救急医学科(受稿 1993.8.10)〔連絡先：干228 相模原市北里 1-15-1 北里大学医学部 脳神経外科 宮坂 佳男〕 (Mailing address: Yoshio MIYASAKA, M.D., Department of Neurosurgery, Kitasato University School of Medicine, 1-15-1 Kitasato, Sagamihara 228, Japan] 


\section{対象と方法}

過去に経験した後頭蓋䆚AVM は 29 例である. 摘出後 の施行されたのは 26 例, 非手術例は 3 例であり, 手術非 施行の理由は高齢, 術前死亡, 手術拒否が各 1 例であった. 26 例の手術成績を手術時の意識障害が 100-300 点 (Japan Coma Scale: JCS)の重症例と, $0-30$ 点の軽症例に分けて Table 1 に示した. 重症例では, Glasgow Outcome Scale (GOS)で, good recovery (GR) 㧍よび moderate disability (MD) まで回復する症例が約半数にすぎなかった。こ のように, 後頭蓋窝 AVM の重症例を多く経験している こともあって, 軽症例に対しても積極的に摘出術を行って きた. Table 1 に示すように， 3 例で術後症状の悪化を見 た。これら軽症例の術後悪化例を提示して悪化の原因と対 策について報告する.

な抢, これら軽症例 15 例は平均年齢 27 歳 ( 4 ～59 歳), 14 例は出血例, 1 例は進行性に小脳症状を示した症例で ある. 手術時期は出血例では 4 例が $7 \sim 14$ 日以内，他の 10 例が 15 日以降に行われた。術前に中等度ないし軽度の 運動失調が各々 5 例，4例に認められた。手術は全例座位 にて, suboccipital infratentorial approachにて施行された。

\section{結＼cjkstart果}

手術成績を AVM の部位と大きさを考慮して検討し， Table 2 に示した。 大きさから見ると, small AVM $(<2$ $\mathrm{cm})$ の症例では悪化例はなかった. moderate AVM (2 $4 \mathrm{~cm})$ の 2 例と, giant AVM $(<6 \mathrm{~cm})$ の 1 例で術後症状 の悪化を認めた。また，これら悪化した 3 例では，AVM がいずれも脳幹まで及んでいた，な抢，悪化例の 2 例の原 因は術後の出血であった。

代表例：術後に症状の増悪を示した代表例を提示する。

<症例 1 > 42 歳, 男性.

臨床経過：1980 年 8 月 24 日，1981 年 8 月 3 日，1982 9 月 23 日にクモ膜下出血 (SAH) のために入院を繰り返し た. 1987 年 7 月 31 日に突発する強い頭痛にて, 同日再度 来院した。神経学的に髄膜刺激症状，右 MLF（medial longitudinal fasciculus) 症候群, 右 Horner 徵候, 左半身 の感覚低下を認めた。

画像所見：CTでは，四丘体槽を中心とした SAH と軽 度の脳室内出血 $(\mathrm{IVH})$ を認めた。椎骨動脈写 $(\mathrm{VAG})$ は上 小脳動脈 (SCA) を feeder とし, Galen 静脈を drainer とす

Table 1 Surgical results of posterior fossa AVMs

\begin{tabular}{lclllll}
\hline & \multicolumn{3}{c}{ Surgical results } & \multicolumn{5}{c}{ Glasgow } & \multicolumn{3}{c}{ Outcome } & Scale) \\
& GR & MD & SD & V & Dead \\
\hline Poor risk $(\mathrm{n}=11)$ & 2 & 2 & 3 & 1 & 3 \\
Good risk $(\mathrm{n}=15)$ & 11 & $2(1)$ & 0 & $1(1)$ & $1(1)$ \\
\hline
\end{tabular}

$\mathrm{AVMs}=$ arteriovenous malformations, Poor risk $=$ Level of consciousness at the time of admission was 100-300 according to the Japan Coma Scale (JCS), Good risk $=$ Level of consciousness at the time of admission was $0-30$ according to the JCS, Number in parentheses=patients with postoperative neurological deterioration, $\mathrm{GR}=$ good recovery, $\mathrm{MD}=$ moderate disability, $\mathrm{SD}=$ severe disability, $\mathrm{V}=$ vegetative state

Table 2 Sizes, locations of AVMs and surgical results

\begin{tabular}{lcccl}
\hline \multicolumn{1}{c}{ AVMs location } & \multicolumn{4}{c}{ Sizes of AVMs } \\
& Small & Moderate & Large & Giant \\
\hline $\begin{array}{l}\text { Hemisphere } \\
\text { Hemisphere middle }\end{array}$ & 6 & $3\left(1^{*}\right)$ & 0 & 0 \\
$\quad$ cerebellar peduncle & 0 & $1(1)$ & 0 & 0 \\
Vermis, hemisphere $\sim$ pons & 0 & 0 & 0 & $1\left(1^{*}\right)$ \\
Vermis & 1 & 0 & 0 & 0 \\
Vermis $\sim$ midbrain, pons & 0 & $1\left(1^{*}\right)$ & 0 & 0 \\
Tonsil & 2 & $0\left(1^{*}\right)$ & 0 & 0 \\
\hline Total & 9 & 5 & 0 & 1 \\
\hline
\end{tabular}

Sizes of AVMs $=$ Small $(<2 \mathrm{~cm})$, Moderate $(2 \sim 4 \mathrm{~cm})$, Large $(4 \sim 6 \mathrm{~cm})$, Giant $(>6 \mathrm{~cm})$, Number in parentheses=patients with postoperative neurological deterioration, ${ }^{*}=$ patients with postoperative intracerebral hemorrhage 


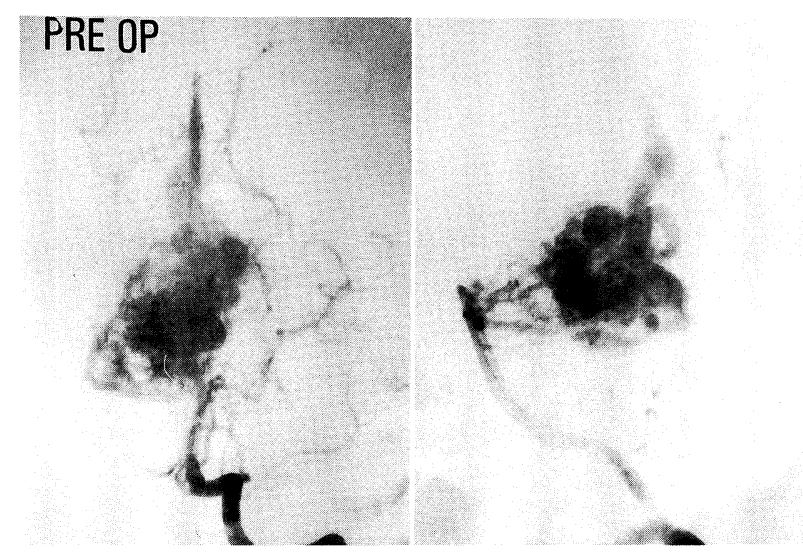

Fig. 1 Preoperative left vertebral angiograms in Case 1, anteroposterior (left) and lateral (right) views, demonstrating a moderate sized AVM in the cerebellar vermis. The AVM is supplied by the bilateral superior cerebellar arteries and drained into the vein of Galen.

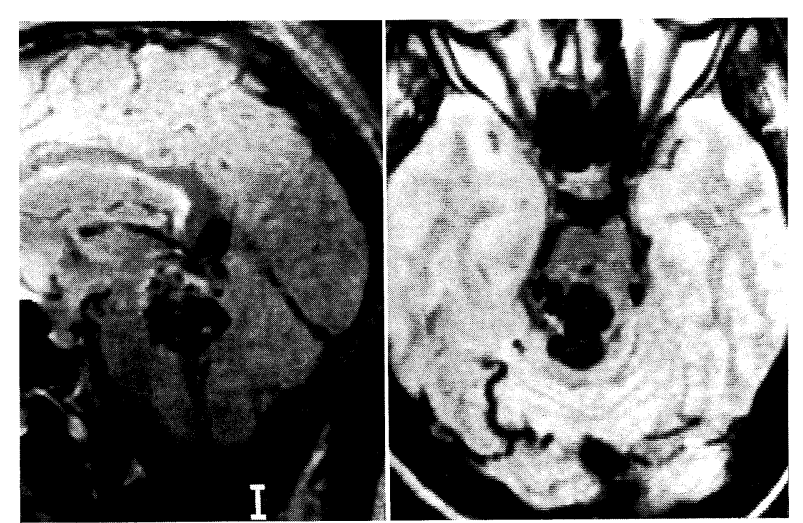

Fig. 2 Same case as in Fig. 1. Preoperative sagittal (left) and axial (right) proton-weighted (TR 2000/ TE 60 msec) MR images showing an AVM in the cerebellar vermis. Extension of the nidus from the cerebellar vermis to the midbrain and the pons is suggested.

る中型の AVM が認められた Fig. 1). AVM は小脳虫部 に主として位置していることが示唆された. MRI では, nidus が小脳虫部から一部中脳，橋背側部に伸展している ことを疑わせた(Fig. 2).

手術所見：1987 年 9 月 22 日に，座位で infratentorial supracerebellar approachにて摘出術を施行した. nidusは 小脳虫部から四丘体槽を埋めつくし，更に，前方で脳幹部 に埋没していた。虫部と四丘体槽に位置するAVMのみ の摘出に終った。

手術経過 : 術後軽度の意識障害, 両側動眼神経麻痺が認 められたが，1 カ月で意識は清明となり，動眼神経麻痺も 改善傾向を示した。術後のVAGでは,AVM は縮小した ものの脳幹部の nidus が残存していた Fig. 3). 残存部 AVM は脳幹部に位置するものの, 形態は予想以上に
POSTOP

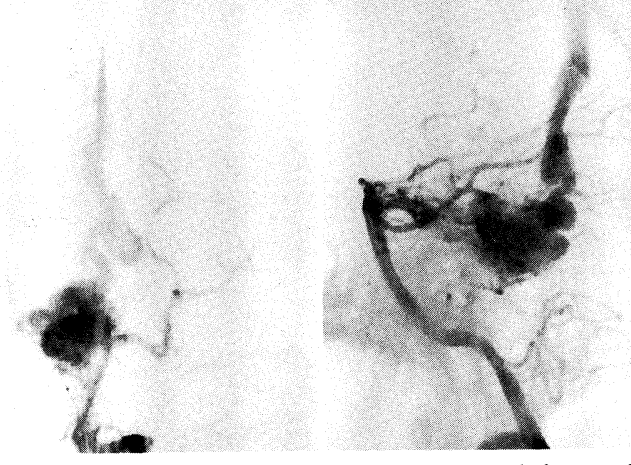

Fig. 3 Same case as in Fig. 1. Postoperative left vertebral angiograms, anteroposterior (left) and lateral (right) views, showing a small residual nidus in the brainstem.

compactであったことと，初回手術による神経脱落症状が 改善傾向を示したため, 再手術を検討中であった。術後約 4 カ月後の 1988 年 2 月 5 日に突然昏睡状態となった. CT では脳幹部に実質内出血が見られ，同 3 月 5 日死亡した.

$<$ 症例 $2>29$ 歳, 女性.

臨床経過：1991 年 11 月 6 日, 頭痛, 数回の嘔吐, 歩行 時の体動摇感および左手の運動が拙劣であることを主訴に 他院を受診. CTにて SAH を疑われて, 同 11 月 9 日，当 院に転科となった，来院時神経学的に注視方向性眼振，両 側外転神経麻痺, 左側運動失調を認めた。

画像所見：来院時の CT では, 小脳半球上面に軽度の $\mathrm{SAH}$ を認めた。 また, 閉塞性水頭症の所見が見られたた めに，緊急で脳室腹腔交通術を施行した，通常のVAGで は，最大径約 $8 \mathrm{~cm}$ の小脳虫部を中心とする giant AVM が認められた Fig. 4-A)。しかし, feeder が明瞭に描出さ れないために，超選択的血管撮影を行ったところ， Fig. 4-B に示すように, 左右の SCA, 右後下小脳動脈 (PICA), 左前下小脳動脈 (AICA)が主たる feederであることが確認 された. 更に, 右後大脳動脈, 左内頸動脈テント枝, 椎骨 動脈筋肉枝, 外頸動脈 (右中硬膜動脈, 右上行性咽頭動脈) がfeeder として関与していた，MRIでは，AVMは小脳 虫部に主座を置き，部分的に中脳および肺背側部に伸展し ている可能性が示唆された(Fig. 5).

術前塞栓術：giant AVM によるAVM 周囲の脳循環動 態を, 術前に可能な限り, 徐々に正常化させておくために 4 力月間にわたって合計 4 回塞栓術を行った. 塞栓術は, 上記の feeder に超選択的に Balt magic catheter を挿入し て, xylocaine と amytalによる provocative testを行い, テスト陰性の feederに対して, PVA (polyvinyl alcohol foam, 150〜250 $\mu$ ) による塞栓術を施行した. 塞栓後(直達 手術前)のVAGでは, AVMの縮小を認めた(Fig. 4-C). 


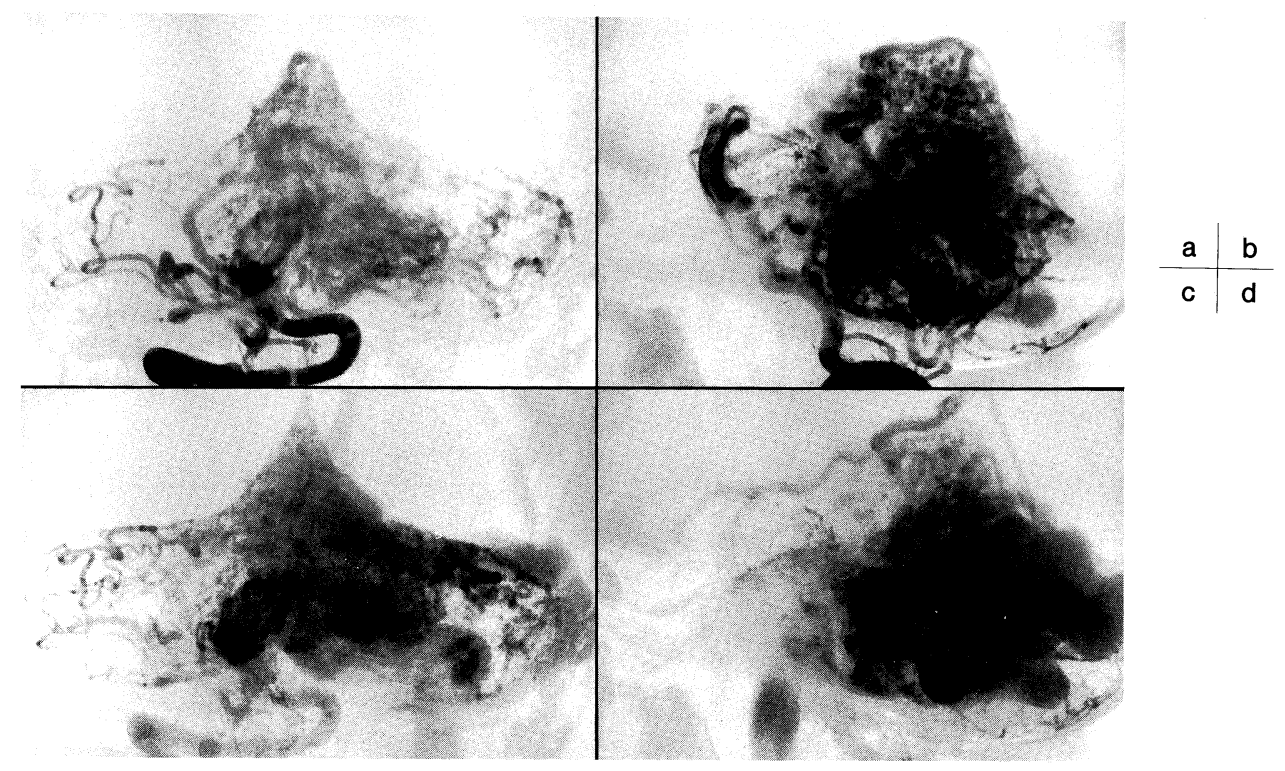

Fig. 4A Preoperative right vertebral angiograms in Case 2 , arterial $(a, b)$ and venous $(c, d)$ phases, anteroposterior $(a, c)$ and lateral $(b, d)$ views, demonstrating a giant AVM in the cerebellar vermis.
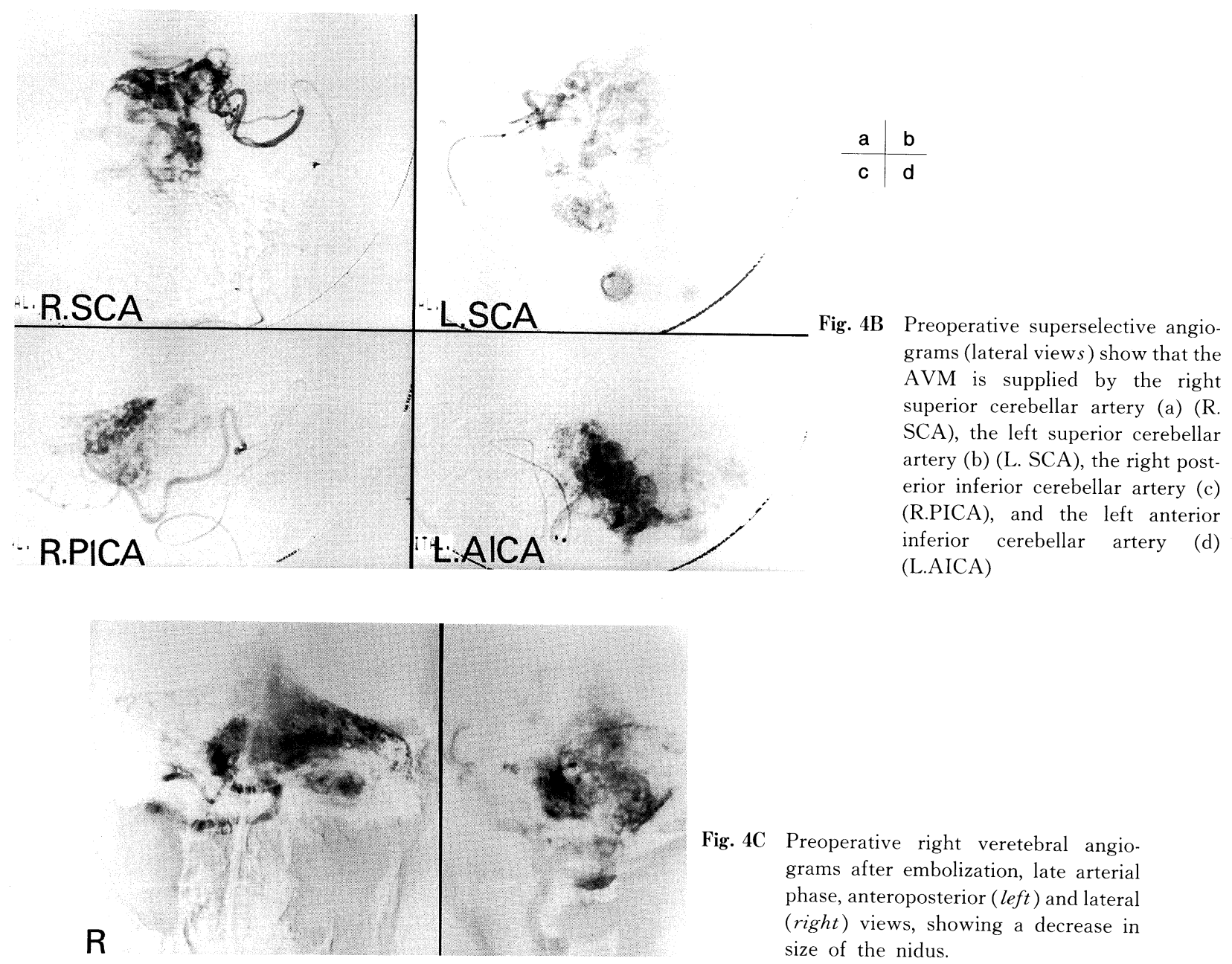

Fig. 4C Preoperative right veretebral angiograms after embolization, late arterial phase, anteroposterior (left) and lateral (right) views, showing a decrease in size of the nidus. 


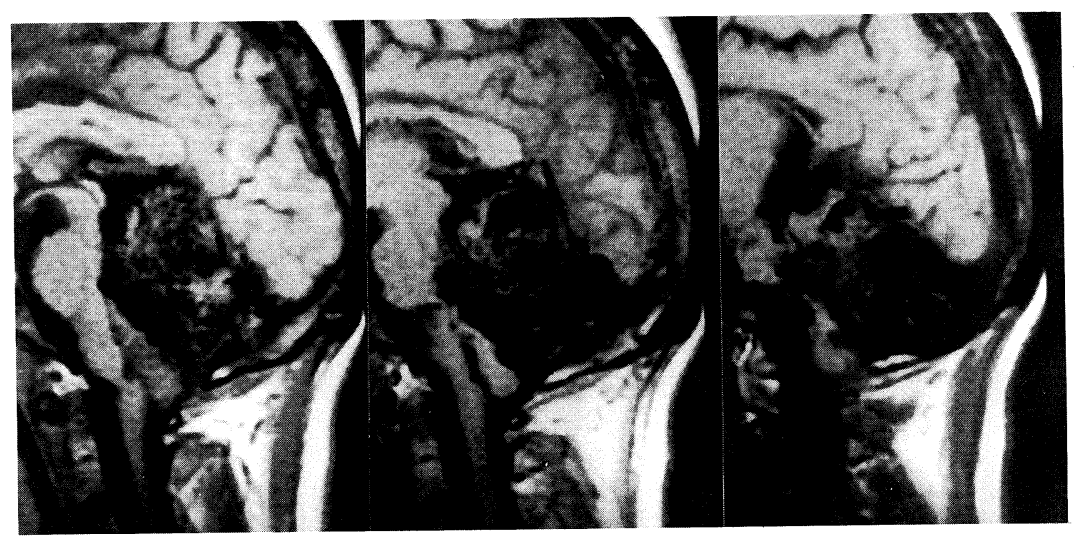

Fig. 5 Same case as in Fig. 4. Preoperative sagittal Tl-weigted MR images (TR $<400 /$ TE $25 \mathrm{msec}$ ) showing an AVM in the cerebellar vermis. Extension of the nidus from the cerebellar vermis to the pons and the midbrain is suggested.

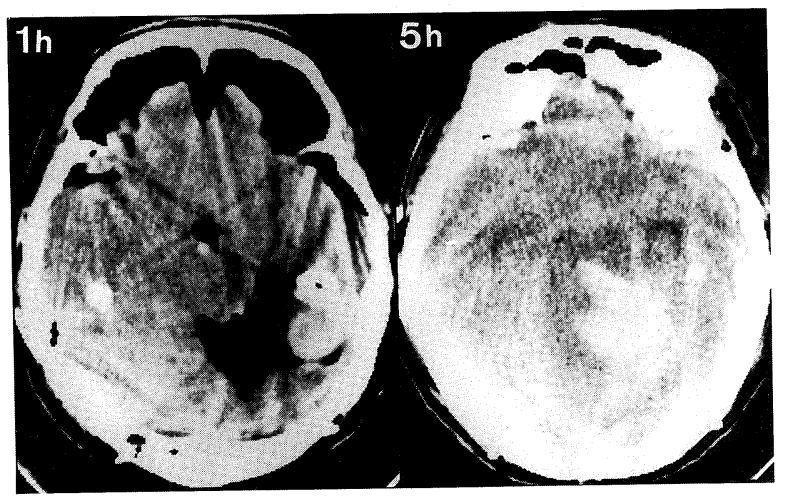

Fig. 6 Same case as in Fig. 4. Postoperative CT scan obtained one hour (left) after the operation showing no intracerebral hematoma. CT scan obtained 5 hours (right) after the operation demonstrating massive intracerebral hematoma. Note the compression of midbrain by the hematoma.

手術所見：1992 年 6 月 9 日に座位にて, suboccipital infratentorial approachにて, 摘出術を施行した. まず main feederである両側 SCA, PICA を早期に露出し, nidus 近

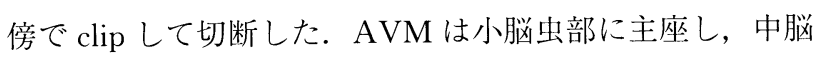
レベルでは, 四丘体槽には nidus が見られたが, 四丘体そ のものには伸展せず, また下方延髄部でも, 髄内への伸展 はなかった，橋では, nidus は第 4 脳室を充満し, 外側部 で両側中小脳脚に伸展していた. AVM は塞栓術によって 部分的に血栓化しており出血量は予想以上に少なく, 輸血 は約 3,000 mlであった. 約 13 時間で摘出術を終えた. 摘 出後約 1 時間にわたって, 止血を確認していたが小脳の腫 脹や異常な出血は認められなかった。 なお,この症例の術 前の平均動脈圧は 90〜 95 $\mathrm{mmHg}$ であり, 手術中は 90〜 $100 \mathrm{mmHg}$ で維持されていた.

術後経過：閉頭後約 1 時間は頭部を 30 度程度挙上した
状態を維持し, その後仰臥位にて CT および術後の VAG を施行した。この間，平均動脈圧はやや高く $110 \sim 120$ $\mathrm{mmHg}$ であった. 術後 1 時間の CTでは出血はなく(Fig. 6-左), VAGでAVMの全剔が確認された(Fig. 7). しか し, feederであった両側 SCA には，著明な stagnating artery の所見が認められた Fig. 7). VAG 終了後から再 び頭部挙上の状態で術後管理を行った. その後平均動脈圧 は110〜120 mmHg で経過した. 術後 5 時間後に脳へルニ アによる瞳孔異常 (右 $5 \mathrm{~mm} \geqq$ 左 $2 \mathrm{~mm}$, 右対光反射消失) が出現し，CT では AVM 摘出部の小脳に massiveな脳内 出血が見られ, 中脳を前方へ圧排していた (Fig. 6-右). 再手術では, 明らかな出血点は見られなかった. その後, 意図的に $\mathrm{Ca}$ 拮抗剂にて平均動脈圧をこの症例の術前のレ ベルと同程度 $(90 \sim 95 \mathrm{mmHg})$ に維持した. しかし, 術後 17 時間後と 4 日後に再度出血を繰返し血腫摘出を行った が, 現在 vegetativeの状態である.

\section{考案}

テント上に比べて, 後頭蓋窩 AVMでは, 重症例の占

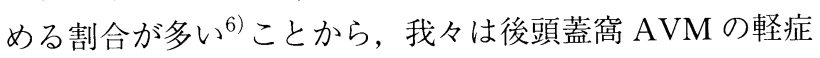
例に対しても積極的に摘出術を施行してきた. その結果, 大多数の症例で良好な成績が得られた(Table 2). しかし 脳幹部を含む後頭蓋窩 AVM や giant AVM の 3 例で満足 すべき結果が得られなかった. 特に, 今回提示した 2 例は 今後, 後頭蓋窩 AVM の治療方針を決定する上で, 重要 な症例と思われるので, 我々の反省を含めて報告した.

後頭蓋窩 AVM の手術成績を文献的に検討した George

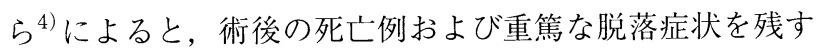
症例の頻度はテント上に比べて約 2 倍であるという。また 脳幹部 AVM のみを別にして検討すると, 更に成績は不 良であったと報告している。このことは後頭蓋窩 AVM 


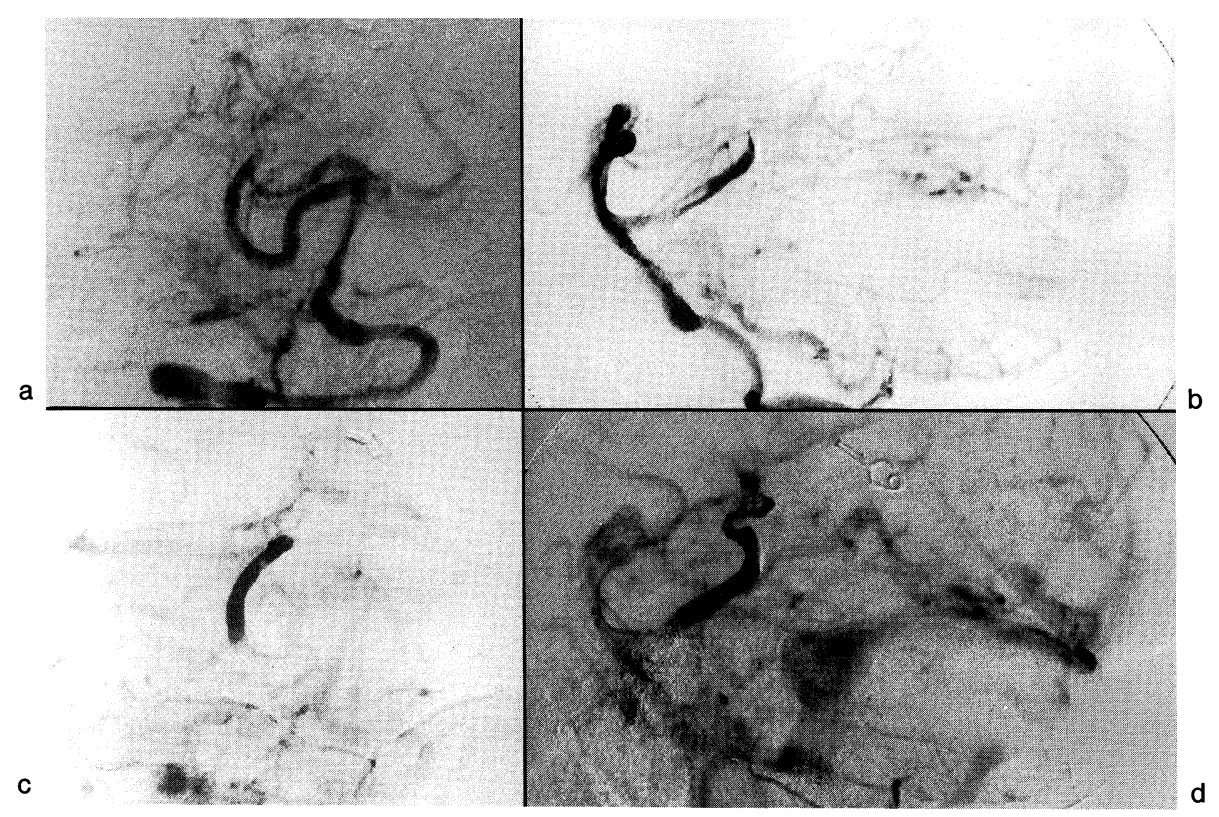

Fig. 7 Same case as in Fig. 4. Postoperative right vertebral angiograms obtained one hour after the operation, arterial $(\mathbf{a}, \mathbf{b})$ and venous $(\mathbf{c}, \mathbf{d})$ phase, anteroposterior (a, c) and lateral (b, d) views, showing complete removal of the AVM. The persistently dilated former feeders demonstrate sluggish arterial flow.

がテント上AVMに比べて種々の問題点のあることを示 唆している，本報告で示したように，後頭蓋窩AVMの 手術の問題点の一つは術後出血であり，その原因と対策を 検討しなければならない。また，他の一つは小脳に限局せ ず脳幹部にまで及ぶ AVM の治療である ${ }^{12) 23) 10) 13) . A V M ~}$ 摘出後の術後出血の原因として, 残存 AVM. normal perfusion pressure breakthrough (NPPB)，不完全な止血. と nidus 摘出後に生じる血管内圧上昇，静脈の還流障害な どが考えられている(1)37)8)11)12)13)。我々の症例 1 では, 脳幹部の残存 AVM が出血の原因であり，このような症 例の対策については後述する。また，症例 2 では残存 AVM はなく, AVM 摘出後の血行力学的な变化が出血に 関与していると思われる. 術直後の VAG (Fig. 7)に示す ように, feederであった SCA はいわゆる stagnating arteryの所見を示した。この所見は AVM 摘出後の feeder の流速の遅延を示し，このような血管では，血管内圧の上 昇が見られる ${ }^{9)}$. 症例 2 では，このような状態に体血圧の 上昇が加わり，更にfeeder 内圧の上昇をきたし，その分 枝から出血をきした可能性がある. Drake $ら^{3)}$ は 51 例の 後頭蓋窩 AVM の手術成績を検討し, 術後悪化例の多く は術後出血に起因すると報告している. 出血例は large $\mathrm{AVM}(\geqq 5 \mathrm{~cm})$ でなかったことと, 術中の脳浮腫や出血が なかったことから, 出血の原因としてNPPB は考え難い としている. Drake $ら^{3)}$ の手術体位は全例が座位であるこ とから，不完全な止血と手術体位を術後早期に仰臥位に戻
すことによる頭蓋内の血管内圧の上昇による出血の可能性 が高いことを指摘している. 実際に出血例の数例で， CT のために 30 分間仰臥位に戻した症例を報告している。座 位と仰臥位では頭蓋内の血管内圧に $20 \mathrm{mmHg}$ の差が見ら れるために，座位手術例では少なくとも 1 日は座位の状態 で術後管理すべきことを強調している，我々の症例 2 もこ のような機序による出血と思われる。このような観点から 症例 2 の反省点について考察する。 この症例は術後の CT と VAG のために，術後約 1 時間後から，約 1 時間にわた って体位は仰臥位の状態に置かれた。残存 AVM は術後 出血の大きな原因であり，その早期の確認と残存部の摘出 術は重要である ${ }^{1) 7)}$. このような理由から症例 2 では検査 のために仰臥位にすることは避けられなかった。しかし， この間の体血圧の管理に問題があり, 最低限術前のレベル で維持すべきであったと思われる. また，検査終了後は半 座位にて管理したものの，やはり体血圧がやや高值を示し ていたことが術後の出血に関与していた可能性がある。こ のような術後管理の問題点とともに, 症例 2 のような giant AVMでは周囲脳組織の血行動態をできるだけ正常 化させてから摘出術を施行すべきことが強調されている1) 12)。しかし, 術前の塞栓術の回数や手術までの期間に関 する明確な結論は出ていない。我々も術前に 4 回にわたっ て，塞栓術を施行したものの，その後は待機中の出血を危 惧して摘出術に踏み切った。術後の経過を見ると，更に多 数回の術前塞栓術を行い，AVM 周囲脳の血行動態を更に 
正常に近づけるべきであったと思われる.

一方，症例 1 のように脳幹を含むAVM の治療は後頭 蓋窩 AVM の重要な問題点である ${ }^{210)}$ 。出血で発症し, 小 型で脳幹部の表在性の AVM について積極的に摘出術を 施行し良好な成績を上げている報告もある ${ }^{2) 10)}$. MRIの 出現以降，AVMの局在がより明瞭となったことも積極的 な摘出術に貢献している. 今回報告した症例 1 では, 脳幹 部を占拠する残存部分の摘出を考慮中に再出血にて死亡し た. 当時摘出術以外に出血を防止する手段がなかったため に再手術を考慮していた。しかし, 初回手術にて, 改善傾 向は見られたものの神経脱落症状が出現しており, 再手術 にて残存部が摘出されたとしても，かなりの症状の増悪を 覚悟しなければならなかったであろう。放射線壊死の危険 性を捨てきれないものの, 最近ならば, このような症例を 経験したならば, $\gamma$-surgery ${ }^{5)}{ }^{14)}$ の併用を考慮すべきであろ j.

\section{結語}

後頭蓋窩 AVM で満足すべき結果が得られなかった症 例の詳細を報告し，原因と対策について述べた。

\section{文献}

1) Batjer H, Samson D: Arteriovenous malformations of the posterior fossa. Clinical presentation, diagnostic evaluation, and surgical treatment. J Neurosurg 64: 849-856, 1986

2) Chyatte D: Vascular malformations of the brain stem. J Neurosurg 70: 847-852, 1989
3) Drake CG, Friedman AH, Peerless SJ: Posterior fossa arteriovenous malformations. J Neurosurg 64: 1-10, 1986

4) George B, Celis-Lopez M, Kato T, et al: Arteriovenous malformations of the posterior fissa. Acta Neurochir (Wien) 116: 119-127, 1992

5) Lunsford LD, Kondziolka D, Flickinger JC, et al: Stereotactic radiosurgery for vascular malformations of the brain. Neurosurgeons 12: 288-296, 1993

6）宮坂佳男, 入倉克己, 北原行雄, ほか: 脳動静脈奇形重症 例の検討. 脳神経外科 16: 733-740, 1988

7）宮坂佳男, 田中柳水, 田中千彦, ほか：大型 AVM の手術 成績に関する諸因子と対策. 脳卒中の外科 18: 251-256, 1990

8) Miyasaka Y, Yada K, Ohwada $\mathrm{T}$, et al: Hemorrhagic venous infarction after excision of an arteriovenous malformation. Neurosurgery 29: 265-268, 1991

9) Miyasaka Y, Yada K, Ohwada T, et al: Pathopysiologic assessment of stagnating arteries after removal of arteriovenous malformations. AJNR 14: 15-18, 1993

10) Solomon RA, Stein BM: Management of arteriovenous malformations of the brain stem. J Neurosurg 64: 857-864, 1986

11) Spetzler RF, Wilson CB, Weinstein $P$, et al: Normal perfusion pressure breakthrough theory. Clin Neurosurg 25: 651-672, 1978

12) Spetzler RF, Martin NA, Carter LP, et al: Surgical management of large AVM's by staged embolization and operative excision. J Neurosurg 67: 17-28, 1987

13) Stein BM, Solomon RA: Surgical approaches to posterior fossa arteriovenous malformations. Clin Neurosurg 37: 353-371, 1989

14) Steiner L, Lindquist C, Adler JR, et al: Clinical outcome of radiosurgery for cerebral arteriovenous malformation. J Neurosurg 77: 1-8, 1992 